\title{
Zastosowanie pylu bazaltowego, jako substytutu piasku w zaprawie i betonie cementowym
}

\author{
Magdalena Dobiszewska \\ Katedra Mechaniki Konstrukcji, Wydział Budownictwa, Architektury i Inżynierii Środowiska, \\ Uniwersytet Technologiczno-Przyrodniczy im. Jana i Jędrzeja Śniadeckich w Bydgoszczy, \\ e-mail: magdalena.dobiszewska@utp.edu.pl
}

Streszczenie: W pracy przedstawiono wyniki badań dotyczących możliwości zastosowania odpadowego pyłu bazaltowego do produkcji zapraw oraz betonów cementowych. Wykorzystane w badaniach pyły stanowią odpad powstający podczas obróbki kruszywa stosowanego do produkcji mas mineralno-asfaltowych (MMA). Utylizacja tych odpadów stanowi obecnie duży problem w wielu wytwórniach MMA. Celem określenia wpływu dodatku pyłu bazaltowego na wybrane właściwości zapraw przeprowadzono badania wytrzymałości na zginanie i ściskanie po 2, 28 i 56 dniach dojrzewania próbek, określono mrozoodporność zapraw a także zdolność do kapilarnego podciągania wody, nasiąkliwość oraz współczynnik rozmiękania zapraw. Wpływ dodatku pyłu bazaltowego na parametry termoizolacyjne zapraw określono na podstawie pomiaru współczynnika przewodzenia ciepła w aparacie płytowym TCA 300. Przeprowadzone badania dotyczyły również analizy wpływu dodatku pyłu bazaltowego na wybrane właściwości betonu. W tym celu zbadano wytrzymałość betonu na ściskanie, po 28, 90 i 180 dniach oraz mrozoodporność. Odpadowy pył bazaltowy stanowił częściowy zamiennik piasku w ilości 0-30\% masy piasku w przypadku zapraw oraz w ilości 0-20\% masy piasku w przypadku betonów. Wyniki przeprowadzonych badań wskazują na to, że pył bazaltowy może być stosowany do produkcji zapraw i betonów cementowych, jako substytut piasku naturalnego. Zastąpienie części piasku przez pył bazaltowy wpłynie na poprawę niektórych właściwości tych materiałów oraz pozwoli na zagospodarowanie odpadu przemysłowego.

Słowa kluczowe: odpadowy pył bazaltowy, zaprawa cementowa, beton, wytrzymałość na ściskanie, mrozoodporność.

\section{Wprowadzenie}

Przemysł cementowy ma znaczny wpływ na środowisko. Produkcja cementu jest niezwykle energochłonna, wymaga użycia ogromnych ilości surowców pochodzących ze źródeł naturalnych oraz przyczynia się do emisji dużych ilości ditlenku węgla do atmosfery. Zapotrzebowanie na surowce naturalne do produkcji materiałów budowlanych ciągle rośnie a źródła ich pozyskiwania są już na wyczerpaniu. Negatywnym skutkiem uprzemysłowienia gospodarki jest niewątpliwie wzrost produkcji odpadów przemysłowych. Roczna produkcja odpadów przemysłowych oraz rolnych na świecie, sięga 2500 milionów ton [1]. Konieczność utylizacji tych odpadów stanowi poważny problem, zarówno ze względu na ograniczenia dotyczące miejsc ich składowania, jak i rygorystyczne normy środowiskowe związane z ilością i jakością wytwarzanych odpadów. Jednym ze sposobów zagospodarowania odpadów oraz produktów ubocznych jest ich recykling i wykorzystanie do produkcji materiałów budowlanych, co jest zgodne z zasadą zrównoważonego rozwoju. To wszystko doprowadziło do rozwoju badań dotyczących możliwości wykorzystania niektórych odpa- 
dów w przemyśle betonowym i cementowym. Piasek naturalny powszechnie stosowany jest w produkcji betonu, jako kruszywo drobne. W wielu krajach obserwuje się obecnie znaczny niedobór odpowiedniej jakości piasku naturalnego, który może być stosowany do produkcji betonu [2]. Dlatego poszukuje się innych materiałów, które stanowić mogą częściowy zamiennik piasku. Wykorzystanie różnego rodzaju odpadów przemysłowych w produkcji betonu, nie tylko redukuje zużycie surowców naturalnych, ale pozwala także na zagospodarowanie odpadów w wielu przypadkach uciążliwych dla środowiska. Granulowany żużel wielkopiecowy, popiół lotny, czy też pył krzemionkowy, stosowane powszechnie jako dodatki mineralne do cementu, mogą być również wykorzystane w betonie, jako częściowy zamiennik piasku [2]. W literaturze przedstawia się badania dotyczące możliwości wykorzystania również innych odpadów [3-20]. Dodatek pyłu marmurowego [3-6], kwarcowego [7, 8], mączki bazaltowej [9-16], granitowej [7, 17], czy też wapiennej [5, 6, 8, 10, 18-20], pozytywnie wpływa na właściwości reologiczne zapraw i mieszanek betonowych, wytrzymałość cementu i betonu a także na ich trwałość. Wymienione odpady, powstają podczas procesu mechanicznej obróbki lub odpylania kruszyw mineralnych stosowanych do produkcji materiałów budowlanch. Najczęściej występują w formie pyłów, przez co są niebezpieczne dla środowiska, z uwagi na nadmierne pylenie i problem z ich składowaniem. Skład chemiczny i mineralny pyłów sprawia, iż mogą być one stosowane do produkcji zapraw cementowych i betonów, jako częściowy substytut kruszywa drobnego lub nawet cementu.

Pyły skalne, często nazywane mączkami, stosowane są w betonie i w zaprawie cementowej przede wszystkim jako dodatki inertne. Ich pozytywne oddziaływanie na niektóre właściwości zaprawy cementowej i betonu związane są przede wszystkim z efektem wypełniacza, czego konsekwencją jest doszczelnienie struktury matrycy cementowej a tym samym poprawa, między innymi parametrów mechanicznych betonów i zapraw. Nie wszystkie jednak pyły pochodzące z obróbki kruszyw mineralnych mają całkowicie inertny charakter. Z ostatnich badań naukowych wynika, że pył wapienny, bierze udział w hydratacji cementu i ma pewne właściwości wiążące. Drobno zmielony krystaliczny węglan wapnia $\mathrm{CaCO}_{3}$ reaguje z fazą $\mathrm{C}_{3} \mathrm{~A}$, jak również $\mathrm{C}_{3} \mathrm{~S}, \beta-\mathrm{C}_{2} \mathrm{~S}$ oraz $\mathrm{C}_{4} \mathrm{AF}$ i w wyniku tego powstają dodatkowe produkty hydratacji $[6,20]$. Pyły mineralne charakteryzują się dużo większą powierzchnią właściwą od piasku. Stąd stosowanie ich, jako częściowego zamiennika kruszywa drobnego, zwiększa znacznie wodożądność zapraw cementowych oraz mieszanek betonowych i pogarsza ich urabialność $[4,7,18$, 19]. W celu uzyskania założonej konsystencji, koniecznym staje się wówczas zwiększenie ilości wody wraz ze wzrostem zawartości pyłu, co prowadzi z kolei do większego skurczu. Na podstawie analizy literatury można sformułować wniosek, że dodatek pyłu mineralnego, pozytywnie wpływa na parametry wytrzymałościowe zapraw i betonów cementowych a także trwałość,

W pracy przedstawiono wyniki badań dotyczących możliwości wykorzystania dodatku odpadowego pyłu bazaltowego w zaprawach i betonach cementowych. Pył, będący odpadem powstającym podczas produkcji mieszanki mineralno-asfaltowej, stosowany był jako częściowy zamiennik piasku.

\section{Procedura badań}

\subsection{Istota badań}

Rozważany w pracy problem dotyczy możliwości wykorzystania odpadowego pyłu bazaltowego, jako składnika zaprawy cementowej oraz betonu. Badania polegały na tym, że pył włączany był w skład mieszanek w taki sposób, że zastępował częściowo piasek. 
Celem ustalenia wpływu pyłu bazaltowego na niektóre właściwości kompozytów cementowo-kruszywowych, zbadano cztery różne zaprawy cementowe oraz trzy betony. Wykonano badania zaprawy referencyjnej, tj. bez dodatku pyłu bazaltowego, którą oznaczono jako C0 oraz trzech zapraw $\mathrm{C} 1, \mathrm{C} 2$ i C3, w których pył bazaltowy stanowił odpowiednio 10, 20 i 30\% masy piasku. Kolejne badania dotyczyły betonu, w którym pył również stanowił zamiennik piasku w ilości 10 i 20\%. Próbki te oznaczono odpowiednio B1 i B2. Mianem B0 oznaczono beton referencyjny, tj. wykonany bez dodatku pyłu bazaltowego.

\subsection{Material badawczy}

Zastosowany w badaniach pył mineralny jest odpadem powstającym w procesie produkcji mieszanki z kruszywa twardego w otaczarce, która wykorzystywana jest do produkcji mas mineralno-asfaltowych MMA. Pył ten pozyskiwany jest w procesie suszenia kruszyw w temperaturze ok. $200^{\circ} \mathrm{C}$. Wychwytywany jest on w filtrze tkaninowym otaczarki i następnie gromadzony w specjalnym zbiorniku. Do produkcji mas mineralno-asfaltowych stosuje się twarde kruszywo mineralne, które pochodzi głównie z kopalni, co oznacza, że powstały pył - traktowany jako odpad - ma zbliżone właściwości do skał, z których powstał. Zastosowane w badaniach pyły mineralne pochodziły z kruszenia skał bazaltowych. Skład tlenkowy oraz uziarnienie pyłów przedstawiono w Tab. 1 i na Rys. 1. Powierzchnia właściwa pyłów wyznaczona aparatem Blaine a wynosi $3500 \mathrm{~cm}^{2} / \mathrm{g}$ a gęstość $2,99 \mathrm{~g} / \mathrm{cm}^{3}$. Uziarnienie maczki jest monomodalne, dominującą ostrokrawędziste nieregularne ziarna o średnicy $15 \mu \mathrm{m}$. Ziarna z przedziału od 0,1 do $100 \mu \mathrm{m}$ stanowią $90 \%$ badanego pyłu.

Tabela 1. Skład chemiczny pyłu bazaltowego PB i cementu CEM

\begin{tabular}{lcccccccccc}
\hline \multirow{2}{*}{ Mat. } & $\mathrm{SiO}_{2}$ & $\mathrm{Al}_{2} \mathrm{O}_{3}$ & $\mathrm{Fe}_{2} \mathrm{O}_{3}$ & $\mathrm{CaO}$ & $\mathrm{MgO}$ & $\mathrm{SO}_{3}$ & $\mathrm{~K}_{2} \mathrm{O}$ & $\mathrm{Na}_{2} \mathrm{O}$ & $\mathrm{Cl}^{-}$ & LOI \\
\cline { 2 - 11 } & \multicolumn{7}{c}{$[\%]$} \\
\hline PB & 38,16 & 12,68 & 15,88 & 15,16 & 7,66 & 0,20 & 0,83 & 2,91 & 0,068 & 4,16 \\
\hline CEM & 19,67 & 4,83 & 3,20 & 64,50 & 1,39 & 2,34 & 0,54 & 0,19 & 0,075 & 2,89 \\
\hline
\end{tabular}

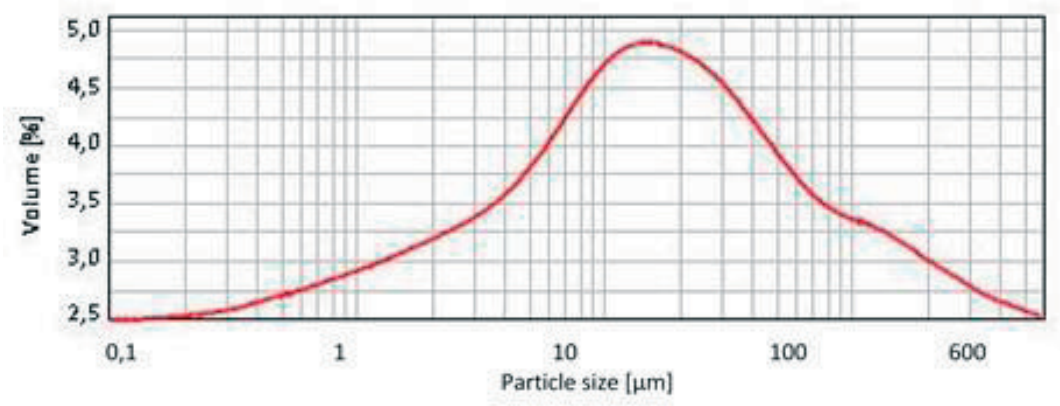

Rys. 1. Krzywa uziarnienia pyłu bazaltowego

Skład chemiczny pyłu jest typowy dla skał bazaltowych. W składzie tym dominują tlenki krzemu $\mathrm{SiO}_{2}$ i glinu $\mathrm{Al}_{2} \mathrm{O}_{3}$ stanowiące $56 \%$ wagowo, oraz tlenki wapnia $\mathrm{CaO}$ i żelaza $\mathrm{Fe}_{2} \mathrm{O}_{3}$. Obraz makroskopowy SEM pyłu bazaltowego oraz dyfraktogram jego składu mineralnego przedstawiono na Rys. 2. W składzie mineralnym pyłu dominują: pirokseny z grupy augitu/diopsyd, amfibole z grupy hornblendy i plagioklazy zasobne w cząsteczkę anortytową. Obok tych faz krystalicznych występuje zeolit - analcym i skaleniowiec nefelin. W badanym pyle prawie w ogóle nie stwierdzono obecności minerałów ilastych (śladowe ilości illitu, około 1-2\% ), które są szkodliwym składnikiem zapraw i betonów. 
Badane zaprawy cementowe oraz betony wykonano na bazie cementu portlandzkiego CEM I 42,5 R, którego skład chemiczny przedstawiono w Tab. 1. Do wykonania zapraw cementowych wykorzystano normowy piasek kwarcowy. Betony wykonano z domieszką upłynniającą i napowietrzającą o stałej wartości wskaźnika w/c, który wynosił 0,4. Jako kruszywa drobnego użyto piasku kwarcowego o uziarnieniu 0-2 mm oraz dwóch frakcji kruszywa grubego żwirowego, tj. 2-8 mm oraz 8-16 mm.

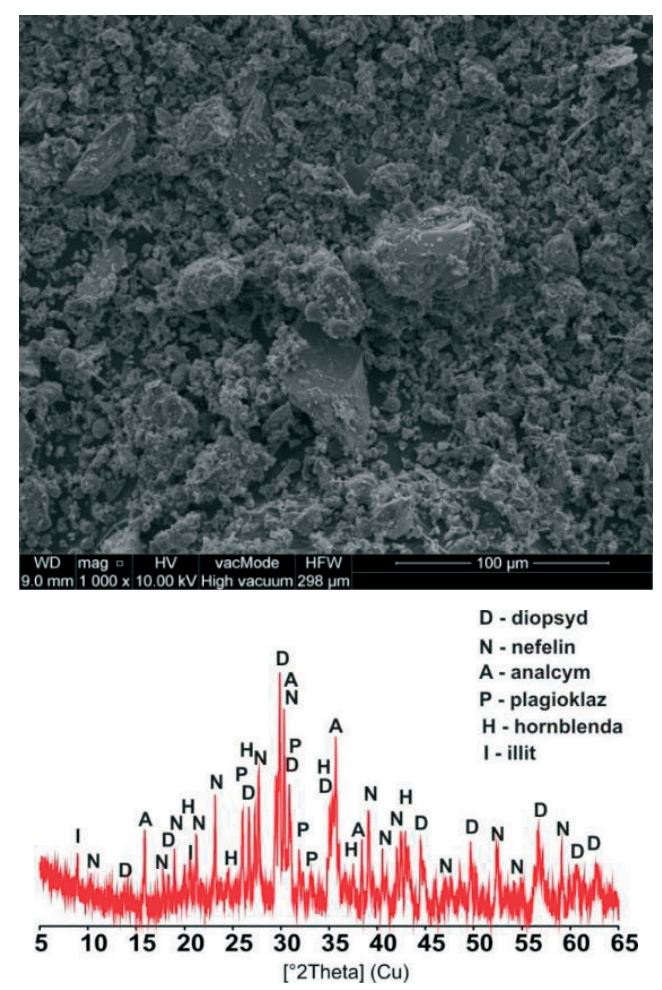

Rys. 2. Obraz makroskopowy SEM oraz dyfraktogram składu mineralnego pyłu bazaltowego

Składy poszczególnych badanych zapraw cementowych oraz betonów przedstawiono w Tab. 2 i 3. Badania zapraw cementowych i betonów wykonywano na próbkach o wymiarach odpowiednio 40x40x160 mm oraz 100x100x100 mm. Wyjątek stanowiły próbki do badań współczynnika przewodzenia ciepła. Najpierw przygotowano próbki o wymiarach 150x150x150 mm, z których następnie wycięto plastry o grubości $35 \mathrm{~mm}$. Wszystkie próbki zostały wykonane i pielęgnowane do czasu badań, zgodnie z normami PN-EN 1961:2006 oraz PN-EN 12390-2:2011.

Tabela 2. Skład zapraw cementowych

\begin{tabular}{|c|c|c|c|c|}
\hline \multirow{2}{*}{$\begin{array}{c}\text { Zaprawa } \\
\text { cementowa }\end{array}$} & Cement & Piasek & Pył bazaltowy & Woda \\
\hline & \multicolumn{4}{|c|}{ [g] } \\
\hline $\mathrm{C} 0$ & 450 & 1350 & 0 & 225 \\
\hline $\mathrm{C} 1$ & 450 & 1215 & 135 & 225 \\
\hline $\mathrm{C} 2$ & 450 & 1080 & 270 & 225 \\
\hline C3 & 450 & 945 & 405 & 225 \\
\hline
\end{tabular}


Tabela 3. Skład mieszanek betonowych

\begin{tabular}{ccccccccc}
\hline Beton & Cement & Piasek & $\begin{array}{c}\text { Kruszywo } \\
2 / 8\end{array}$ & $\begin{array}{c}\text { Kruszywo } \\
8 / 16\end{array}$ & Woda & $\begin{array}{c}\text { Pył } \\
\text { bazaltowy }\end{array}$ & SP & $\begin{array}{c}\text { Dom. } \\
\text { napow. }\end{array}$ \\
\cline { 2 - 9 } & & & & & & {$\left[\mathrm{kg} / \mathrm{m}^{3}\right]$} \\
\hline B0 & 351 & 586 & 547 & 820 & 141 & 0 & 2,2 & 2,1 \\
\hline B1 & 351 & 527 & 547 & 820 & 141 & 59 & 3,5 & 2,1 \\
\hline B2 & 351 & 469 & 547 & 820 & 141 & 117 & 3,5 & 2,1 \\
\hline
\end{tabular}

\subsection{Metodyka badań}

Badania właściwości zapraw cementowych wykonano zgodnie z normami, tj. badanie wytrzymałości na ściskanie i zginanie według PN-EN 196-1, badanie mrozoodporności, nasiąkliwości, zdolności do kapilarnego podciągania wilgoci oraz współczynnika rozmiękania według PN/B-04500. Wartość współczynnika przewodzenia ciepła zapraw określono na podstawie badania aparatem płytowym TCA 300. Pomiar prowadzono zgodnie z normą ISO 8301 a współczynnik przewodzenia ciepła obliczono zgodnie z PN-EN 12664 oraz PN-EN 12667. Wytrzymałość betonu na ściskanie wyznaczono zgodnie z PN-EN 12390-3 po 28, 90 oraz 180 dniach dojrzewania betonu. Mrozoodporność betonu po 50 i 150 cyklach zamrażania i odmrażania określono według PN-B-06250.

\section{Wyniki badań}

\subsection{Wlaściwości zaprawy cementowej}

Wyniki badań wytrzymałości zaprawy cementowej na ściskanie i zginanie oraz mrozoodporności po 25 i 50 cyklach zamrażania i odmrażania przedstawiono w pracy [15]. Badania przeprowadzono na sześciu próbkach, po 28 dniach twardnienia. Na podstawie badań można stwierdzić, że pył bazaltowy pozytywnie wpływa, zarówno na wczesną 2dniową, normową 28-dniową, jak i późniejszą 56-dniową wytrzymałość na ściskanie oraz zginanie (Tab. 4). Wyniki badania wytrzymałości zapraw na ściskanie kształtują się następująco. Dodatek pyłu bazaltowego w ilości 20\% masy cementu przyczynił się do wzrostu wczesnej 2-dniowej wytrzymałości o 38\%. Największy natomiast przyrost wytrzymałości normowej oraz 56-dniowej wystąpił przy dodatku pyłu w ilości 30\% odpowiednio o 40\% oraz o $60 \%$. W przypadku wytrzymałości zaprawy na zginanie tendencja jest podobna. Analiza wyników badań pokazuje, że najkorzystniejszy okazał się udział pyłu w ilości 20\% w przypadku wytrzymałości wczesnej, $10 \% \mathrm{w}$ przypadku wytrzymałości normowej oraz $30 \%$ w przypadku wytrzymałości późniejszej. Odnotowany przyrost wytrzymałości na zginanie, w porównaniu z zaprawą referencyjną, wyniósł odpowiednio: 30, 34\% oraz 30\%.

Tabela 4. Wytrzymałość na ściskanie i zginanie zapraw cementowych w funkcji okresu dojrzewania i zawartości odpadowego pyłu bazaltowego, według [15]

\begin{tabular}{ccccccc}
\hline \multirow{2}{*}{$\begin{array}{c}\text { Zaprawa } \\
\text { cementowa }\end{array}$} & \multicolumn{2}{c}{ Wytrzymałość na ściskanie, [MPa] } & \multicolumn{2}{c}{ Wytrzymałość na zginanie, [MPa] } \\
\cline { 2 - 6 } & \multicolumn{2}{c}{ Okres dojrzewania próbek, [dni] } & \multicolumn{3}{c}{ Okres dojrzewania próbek, [dni] } \\
\cline { 2 - 6 } & 2 & 28 & 56 & 2 & 28 & 56 \\
\hline C0 & 24,3 & 47,9 & 44,8 & 5,6 & 8,3 & 8,9 \\
\hline C1 & 29,7 & 55,8 & 63,1 & 6,4 & 10,9 & 10,2 \\
\hline C2 & 34,2 & 63,6 & 69,6 & 7,3 & 10,6 & 11,3 \\
\hline C3 & 30,5 & 67,3 & 71,6 & 6,2 & 10,8 & 11,4 \\
\hline
\end{tabular}


Na podstawie badań mrozoodporności można jednoznacznie stwierdzić, że dodatek pyłu znacznie poprawia odporność zapraw cementowych na działanie obniżonej temperatury [15] (Rys. 3). Po 25 cyklach zamrażania i odmrażania wytrzymałość na ściskanie zaprawy referencyjnej - w stosunku do próbek sezonowanych w wodzie przez cały okres badania - obniżyła się o 49\%. W przypadku natomiast próbek z dodatkiem pyłu spadek ten był znacznie mniejszy i wyniósł 2,6\% (zaprawa $\mathrm{C} 1$ ), 3,6\% (zaprawa $\mathrm{C} 2$ ) oraz 8,5\% (zaprawa C3). Kontynuacja procesu zamrażania i odmrażania doprowadziła do całkowitej destrukcji zaprawy referencyjnej. Wytrzymałość na ściskanie zapraw po 50 cyklach zamrażania i odmrażania, kształtowała się następująco. W przypadku próbek z dodatkiem pyłu, wytrzymałość na ściskanie obniżyła się o 14\% (zaprawa C1) oraz 5\% (zaprawa C3). Wytrzymałość zaprawy z 20\% dodatkiem pyłu (C2) nie uległa natomiast praktycznie żadnej zmianie w stosunku do próbki porównawczej przechowywanej w wodzie.

a)

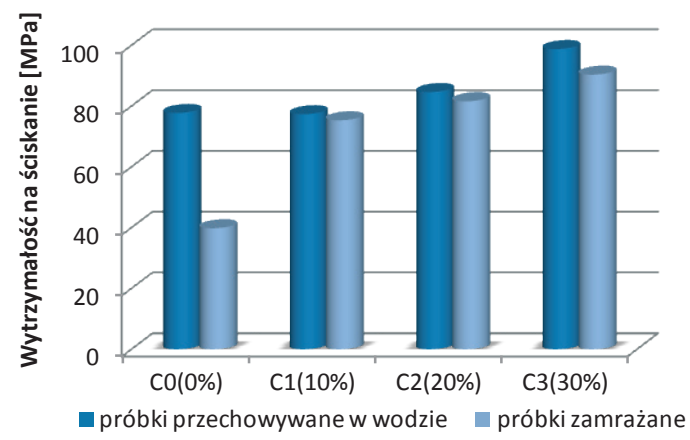

b)

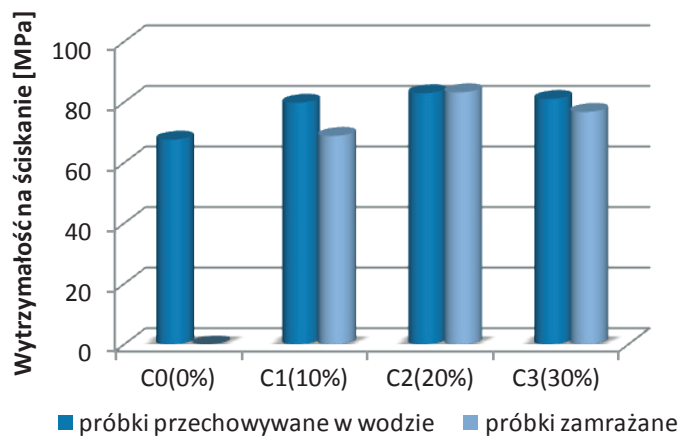

Rys. 3. Wytrzymałość na ściskanie zapraw cyklicznie zamrażanych w funkcji zawartości pyłu bazaltowego [15]: a) 25 cykli zamrażania i odmrażania, b) 50 cykli zamrażania i odmrażania

Cyklicznie zamrażane i odmrażane zaprawy cementowe, poddano również badaniu wytrzymałości na zginanie (Rys. 4). Po 25 cyklach zamrażania i odmrażania, wytrzymałość próbek referencyjnych - w stosunku do próbek porównawczych dojrzewajacych w wodzie - obniżyła się niemal o 89\%. W przypadku natomiast zapraw z pyłem bazaltowym w ilości $10 \%$, wytrzymałość spadła o około $18 \%$ po 25 cyklach oraz o $13 \%$ po 50 cyklach. Dla zapraw wykonanych z 20 i 30\% dodatkiem pyłu nie zaobserwowano istotnych różnic pomiędzy wytrzymałością na zginanie zapraw porównawczych i zapraw podlegających cyklicznemu zamrażaniu i odmrażaniu, zarówno po 25, jak i po 50 cyklach. 
a)

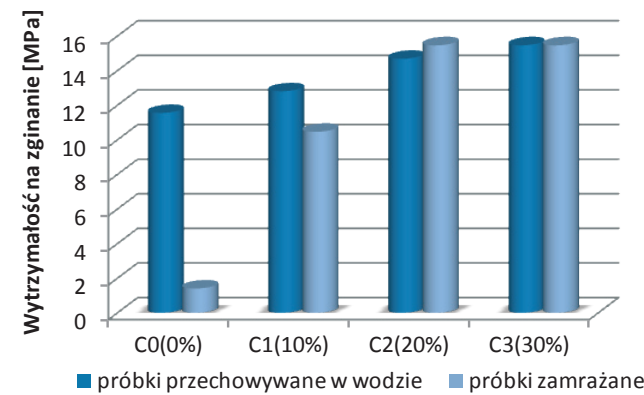

b)

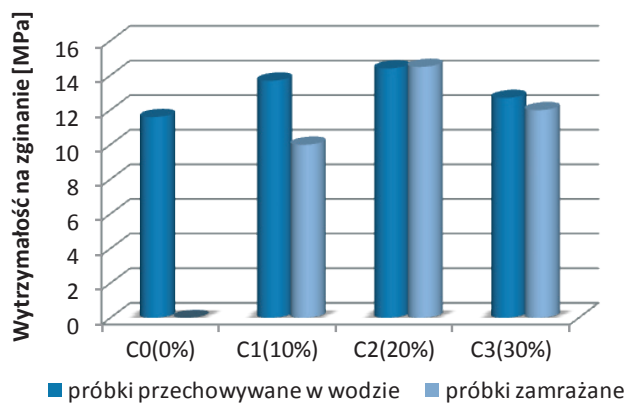

Rys. 4. Wytrzymałość na zginanie zapraw cyklicznie zamrażanych w funkcji zawartości pyłu bazaltowego: a) 25 cykli zamrażania i odmrażania, b) 50 cykli zamrażania i odmrażania

Wyniki badań wpływu pyłu bazaltowego na nasiąkliwość zaprawy cementowej oraz zdolność do kapilarnego podciągania wody przedstawiono w artykule [15]. Badania przeprowadzono na trzech próbkach wysuszonych do stałej masy, po 28 dniach twardnienia. $\mathrm{Na}$ podstawie badań można stwierdzić, że dodatek pyłu w niewielkim stopniu zmienia nasiąkliwość zapraw. Zaobserwowano natomiast znacznie mniejszą zdolność do kapilarnego podciągania wody zapraw wykonanych z pyłem bazaltowym w stosunku do zaprawy referencyjnej, tj. bez dodatku pyłu. Zdolność do kapilarnego podciągania wody określono na podstawie pomiarów przyrostu masy próbek zanurzonych częściowo w wodzie, po upływie 1, 3, 6 oraz 24 godzin (Rys. 5). Pomiary masy próbek po 24 godzinach jednoznacznie wskazują na to, że zdolność do kapilarnego podciągania wody maleje wraz ze wzrostem zawartości pyłu bazaltowego w zaprawie cementowej. Przyrosty mas badanych próbek wyniosły 2,3\%; 2,1\%; 1,9\% oraz $1,5 \%$ odpowiednio dla zapraw $\mathrm{C} 0, \mathrm{C} 1, \mathrm{C} 2$ oraz $\mathrm{C} 3$.

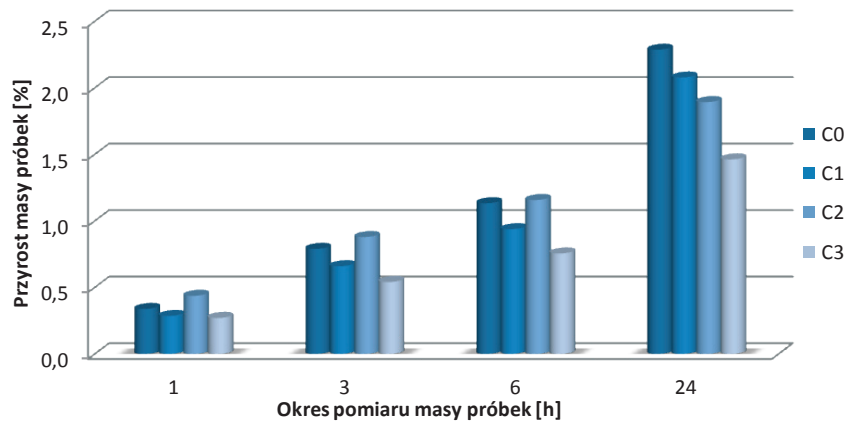

Rys. 5. Przyrost masy zaprawy w wyniku kapilarnego podciągania wody [15] 
Kolejną badaną cechą stwardniałej zaprawy był współczynnik rozmiękania, który określono jako stosunek wytrzymałości na ściskanie próbek moczonych w wodzie przez okres 24 godzin, do wytrzymałości próbek wysuszonych do stałej masy (Rys. 6). Badania przeprowadzono na sześciu próbkach, po 28 dniach dojrzewania. Współczynnik rozmiękania najkorzystniej kształtował się dla zapraw z 20\% zawartością pyłu bazaltowego. Trudno jest określić wyraźną tendencję, można jednak stwierdzić, że dodatek pyłu bazaltowego nie wpływa negatywnie na wytrzymałość zapraw w wyniku ich nawilgocenia.

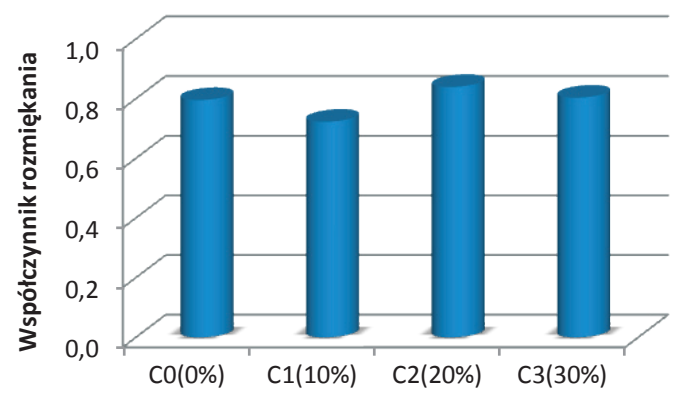

Rys. 6. Wartość współczynnika rozmiękania zaprawy cementowej w funkcji zawartości pyłu bazaltowego

Wpływ dodatku pyłu bazaltowego na parametry termoizolacyjne zapraw określono na podstawie pomiaru współczynnika przewodzenia ciepła w aparacie płytowym TCA 300. Pomiar wykonywany był metodą stacjonarną ze stałą gęstością strumienia cieplnego. Zasada działania urządzenia polega na przepuszczeniu przez próbkę określonego strumienia ciepła i zmierzeniu różnic temperatur powstałych przy ustalonym przepływie ciepła na powierzchniach doprowadzenia i odprowadzenia ciepła. Wyniki pomiarów (Tab. 5) wskazują na to, że wraz ze wzrostem zawartości pyłu bazaltowego maleje wartość współczynnika przewodzenia ciepła a tym samym pył bazaltowy wpływa na poprawę parametrów termoizolacyjnych zapraw.

Tabela 5. Wartości współczynników przewodzenia ciepła zapraw cementowych

\begin{tabular}{cccc}
\hline \multirow{2}{*}{$\begin{array}{c}\text { Zaprawa } \\
\text { cementowa }\end{array}$} & \multicolumn{3}{c}{ Współczynnik przewodzenia ciepła, $\mathrm{W} /(\mathrm{m} \cdot \mathrm{K})$} \\
\cline { 2 - 4 } & $10^{\circ} \mathrm{C}$ & $20^{\circ} \mathrm{C}$ & $30^{\circ} \mathrm{C}$ \\
\hline $\mathrm{C} 0$ & 0,8756 & 0,8627 & 0,8539 \\
\hline $\mathrm{C} 1$ & 0,8367 & 0,8184 & 0,8072 \\
\hline $\mathrm{C} 2$ & 0,8489 & 0,8299 & 0,8184 \\
\hline $\mathrm{C} 3$ & 0,7666 & 0,7543 & 0,7473 \\
\hline
\end{tabular}

\subsection{Wlaściwości stwardnialego betonu}

Celem ustalenia wpływu dodatku odpadowego pyłu bazaltowego na wybrane właściwości betonu, zbadano jego wytrzymałość na ściskanie oraz mrozoodporność. Badania przeprowadzono na sześciu próbkach, po 28, 90 i 180 dniach dojrzewania z wyjątkiem badania mrozoodporności, które przeprowadzono po 28 dniach. Na podstawie rezultatów przeprowadzonych badań stwierdzono, że częściowa zamiana piasku na pył bazaltowy, przyczyniła się do wzrostu 28 dniowej wytrzymałości betonu na ściskanie. Wytrzymałość próbek z zawartością pyłu w ilości 10 i 20\% zwiększyła się w stosunku do próbek referencyjnych o odpowiednio 11 i 8\% [16]. Badania wytrzymałości w późniejszym okresie potwierdzają pozytywny 
wpływ dodatku pyłu na właściwości mechaniczne betonu. Po 90 dniach dojrzewania, wytrzymałość betonu z 10 i 20\% dodatkiem pyłu bazaltowego zwiększyła się odpowiednio o 23 i $19 \%$ w porównaniu do betonu referencyjnego (B0). Po 180 dniach przyrost ten wyniósł $25 \%$ (B1) oraz 15\% (B2). Wyniki badań przedstawiono na Rys. 7.

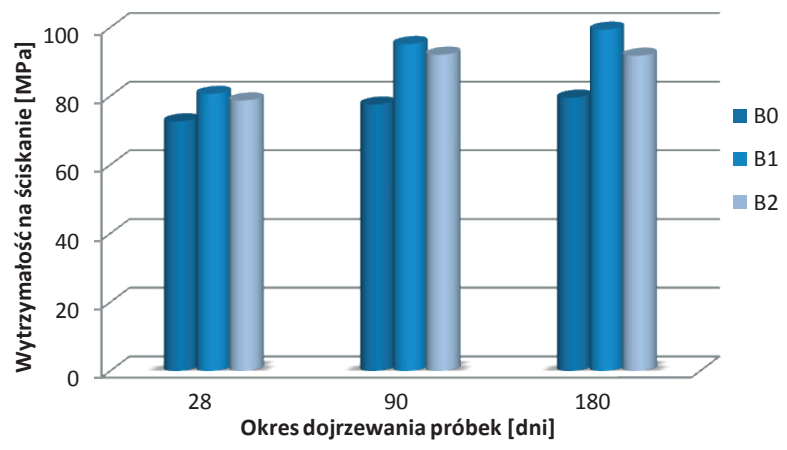

Rys. 7. Wytrzymałość betonu na ściskanie w funkcji okresu dojrzewania i zawartości pyłu bazaltowego

Analiza wyników badań przedstawionych w pracy [16] wskazuje na większą odporność na oddziaływanie mrozu betonu z dodatkiem pyłu, niż betonu referencyjnego. Badania przeprowadzono po 50 i 150 cyklach zamrażania i odmrażania. Spadek wytrzymałości na ściskanie próbek podlegających 50 cyklom zamrażania i odmrażania - w stosunku do próbek porównawczych przechowywanych przez okres badania w wodzie, wyniósł 7,5\% w przypadku betonu referencyjnego (B0) oraz $2 \% \mathrm{w}$ przypadku betonu z $10 \%$ dodatkiem pyłu (B1). Proces zamrażania i odmrażania nie wpłynął natomiast praktycznie w ogóle na wytrzymałość próbek z 20\% zawartością pyłu (B2). Podobne rezultaty uzyskano również po 150 cyklach. Wytrzymałość na ściskanie próbek betonu B0, B1 oraz B2 obniżyła się w porównaniu do próbek przechowywanych w wodzie, odpowiednio o 24,0 oraz $3 \%$.

\section{Wnioski}

Przeprowadzone badania pozwalają na stwierdzenie, że dodatek odpadowego pyłu bazaltowego, poprawia wytrzymałość oraz mrozoodporność zapraw cementowych i betonów. Częściowa zamiana piasku na pył bazaltowy, który charakteryzuje się znacznie mniejszymi wymiarami ziaren, spowodował doszczelnienie struktury matrycy cementowej. Wraz ze wzrostem ilości dodatku pyłu bazaltowego, zmalała całkowita objętość porów, średnica porów oraz porowatość zaprawy cementowej, co bezpośrednio przyczyniło się do wzrostu wytrzymałości i większej odporności zapraw na działanie mrozu [15]. Doszczelnienie struktury matrycy cementowej znalazło bezpośrednie przełożenie na mniejszą zdolność zapraw z dodatkiem pyłu bazaltowego do absorpcji wody. Zjawisko to, które w literaturze określa się, jako tzw. „efektem wypełniacza” jest także przyczyną większej wytrzymałości na ściskanie i mrozoodporności betonu wykonanego z dodatkiem pyłu bazaltowego. Zastosowany w badaniach pył bazaltowy jest odpadem powstającym przy produkcji mas mineralno-asfaltowych MMA. Można oszacować, że odpad ten stanowi około 5\% kruszywa mineralnego stosowanego do produkcji MMA. Zaprezentowane w pracy wyniki badań wskazują, że wykorzystanie pyłu w produkcji budowlanej wpłynie pozytywnie na cechy zapraw i betonów cementowych. Pozwoli to także na efektywne zagospodarowanie odpadów poprodukcyjnych. 


\section{Literatura}

1. Agrawal D., Hinge P., Waghe U.P., Raut S.P. Utilization of industrial waste in construction material - A review. International Journal of Innovative Research in Science, Engineering and Technology 3(1) (2014) 8390-8397.

2. Rashad A. Cementitious materials and agricultural wastes as natural fine aggregate replacement in conventional mortar and concrete. Journal of Building Engineering 5 (2016) 119-141.

3. Neeraj J. Effect of nonpozzolanic and pozzolanic mineral admixtures on the hydration behavior of ordinary Portland cement. Construction and Building Materials 27 (2012) 39-44.

4. Alyamac K.E., Aydin A.B. Concrete properties containing fine aggregate marble powder. KSCE Journal of Civil Engineering 19(7) (2015) 2208-2216.

5. Almeida N., Branco F., de Brito J., Santos J.R. High-performance concrete with recycled stone slurry. Cement and Concrete Research 37 (2007) 210-220.

6. Dhanalaxmi C., Nirmalkumar D.K. Study on the properties of concrete with various mineral admixtures - limestone powder and marble powder (Reviev Paper). International Journal of Innovative Research in Science, Engineering and Technology 4(1) (2015) 18511-18515.

7. Bonavetti V.L., Irassar E.F. The effect of stone dust content in sand. Cement and Concrete Research 24(3) (1994) 580-590.

8. Rahhal V., Bonavetti V., Trusilewicz L., Pedrajas C., Talero R. Role of the filler on Portland cement hydration at early ages. Construcuction and Building Materials 27 (2012) 82-90.

9. Laibao L., Yunsheng Z., Wenkua Z., Zhiyong L., Lihua Z. Investigating the influence of basalt as mineral admixture on hydration and microstructure formation mechanism of cement. Construction and Building Materials 48 (2013) 434-440.

10. Soroka I., Setter N. The effect of fillers on strength of cement mortar. Cement and Concrete Research 7 (1977) 449-456.

11. Uncik S., Kmecova V. The effect of basalt powder on the properties of cement composites. Concrete and Concrete Structures Conference Procedia Engineering 65 (2013) 51-56.

12. Kmecova V., Stefunkova Z. Effect of basalt powder on workability and initial strength of cement mortar. Journal of Civil Engineering and Architectural Research 1(4) (2014) 260-267.

13. Saraya M.E.I. Study physico-chemical properties of blended cements containing fixe amount of silica fume, blast furnace slag, basalt and limestone, a comparative study. Construction and Building Materials 72 (2014) 104-112.

14. Binici H. Effect of crushed ceramic and basaltic pumice as fine aggregates on concrete mortars properties. Construction and Building Materials 21 (2007) 1191-1197.

15. Dobiszewska M., Franus W., Turbiak S. Analiza możliwości zastosowania odpadowego pytu bazaltowego w zaprawie cementowej. Czasopismo Inżynierii Lądowej, Środowiska i Architektury Journal of Civil Engineering, Environment and Architecture JCEEA t. XXXIII z. 63 (nr 1/I/2016) 107-114.

16. Dobiszewska M., Kuziak J., Woyciechowski P., Kępniak M. Główne aspekty trwałości betonu modyfikowanego odpadowym pyłem bazaltowym z odpylania kruszyw w wytwórni MMA. Czasopismo Inżynierii Lądowej, Środowiska i Architektury Journal of Civil Engineering, Environment and Architecture JCEEA t. XXXIII z. 63 (nr 1/I/2016) 115-122.

17. Arivumangai A., Felixkala T. Strength and durability properties of granite powder concrete. Journal of Civil Engineering Research 4(2A) (2014) 1-6.

18. Celik T., Marar K. Effects of crushed stone dust on some properties of concrete. Cement and Concrete Research 26(7) (1996) 1121-1130.

19. Uchikawa H., Hanehara S., Hirao H. Influence of microstructure of the physical properties of concrete prepared by substituting mineral powder for part of fine aggregate. Cement and Concrete Research 26(1) (1996) 101-111.

20. Heikal M., El-Didamony H., Morsy M.S. Limestone-filled pozzolanic cement. Cement and Concrete Research 30 (2000) 1827-1834. 


\title{
Podziękowanie
}

Dziękuję mgr inż. Sylwii Turbiak oraz mgr inż. Łukaszowi Witczakowi za pomoc w przeprowadzeniu badań.

\section{Use of basalt powder in a cementitious mortar and concrete as a substitute of sand}

\author{
Magdalena Dobiszewska \\ Department of Structural Mechanics, Faculty of Civil and Environmental Engineering \\ and Arcitecture, UTP University of Sciences and Technology, Bydgoszcz, Poland, \\ e-mail: magdalena.dobiszewska@utp.edu.pl
}

\begin{abstract}
The present study shows the results of the possibility of using basalt powder in cementitious mortar and concrete. Asphalt mixture production leads to formation of significant amounts of mineral powder. It is used in a present research. Utilization of this waste is a problem in Asphalt Batch Mix Plant. Experiments were carried out to determine an influence of powder basalt on some properties of cementitious mortar. The compressive and flexural strength at 2, 28 and 56 days of curing, freeze resistance, absorptivity, capillary rise of water and softening factor were conducted. Thermal conductivity factor was determined by means of Thermal Conductivity Measuring Instrument TCA 300 to assess a thermal insulation parameters of mortars. Secondly, experiments were also carried out to determine an influence of addition of powder basalt on some properties of concrete. The compressive strength at 28,90, 180 days of curing and freeze resistance were conducted. Cementitious mortars and concrete were prepared with powder basalt as a partial substitute of sand in amount of $0-30 \%$ and $0-20 \%$ sand mass respectively. The results show that powder basalt can be use as an effective substitute of fine aggregate in cementitious mortar and concrete. Use of the powder basalt as a partial substitution of sand improves some properties of cementitious mortar and concrete and anable for the management of industrial waste.
\end{abstract}

Keywords: waste powder basalt, cementitious mortar, concrete, compressive strength, freeze resistance. 
